\title{
تقدير دالة استجابة العرض لمحصول الطماطم الثتوى فى مصر
}

فائقة عباس قرني أحدد، ياسر عبدالحميد عبدالراضى دياب، ‘حسين حسن على آدم، " عبد العاطى محمد محمود على؛

\section{الملخص}

يعتبر محصول الطماطم من أهم محاصيل الخضر فى مصر حيث يحظى باهتمام كبير من قبل الدولة والمزارع والمستهلك، وتعد الطماطم من محاصيل الخضر الهامة فى التركيب المحصولى الدصرى باعتبارها من الدحاصيل الغذائية والتصنيعية التى تقوم عليها بعض الصناعات الغذائية، يهدف هذا البحث إلى دراسة المؤشرات الإتتاجية والاقتصادية وتتدير دوال استجابة العرض لمحصول الطماطم الثتوى فى مصر، وذلك للوقوف على أهم العوامل الاقتصادية المؤثرة على المساحة المزروعة لهذا المحصول خلال الفترة (ه... ب-

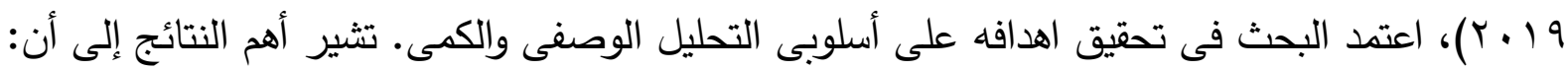
المساحة المزروعة والإنتاج الكلى لمحصول الطماطم لإجمالى العروات أخذت اتجاها عاماً متناقصاً بمعدل

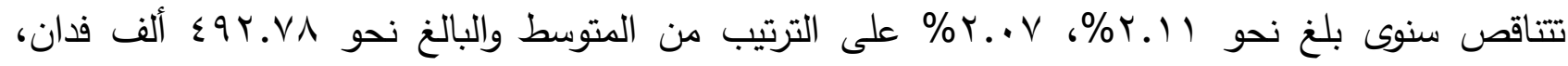
ـ ؟. اء ا N ألف طن، بينما لم تثبت المعنوية الإحصائية للإنتاجية الفدانية، وبالنسبة لدحصول الطماطم الثتوى

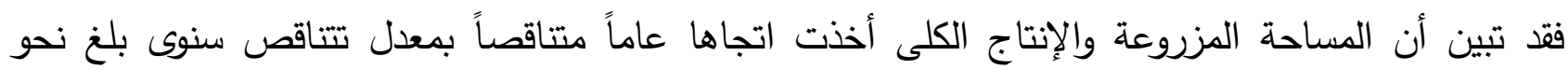

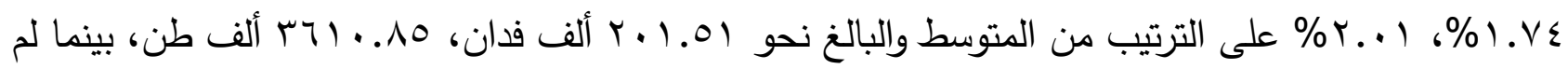

تثبت المعنوية الإحصائية للإنتاجية الفدانية. وبدراسة المؤشرات الاقتصادية لمحصول الطماطم الثتوى وهى الإيراد الكلى، التكاليف الإنتاجية، السعر

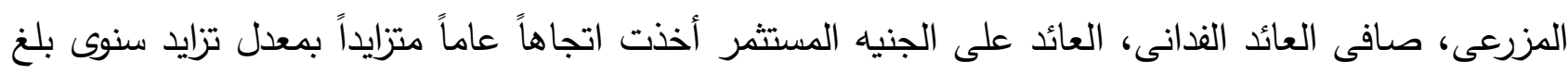

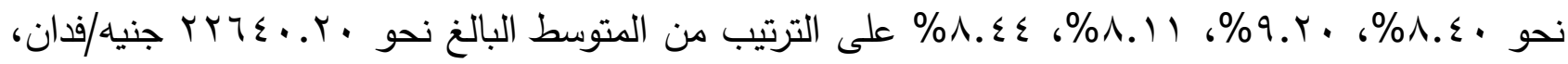

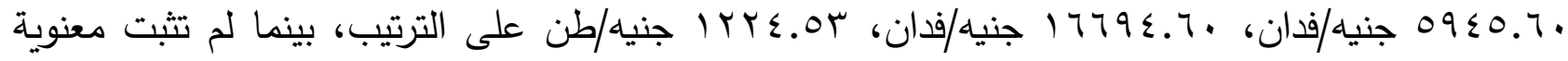
التغير فى العائد على الجنيه المستثمر . التقدير الإحصائى لدوال استجابة العرض للمتغيرات المرتبطة بالمحصول فقد تبين استجابة المزارع للتكاليف الإنتاجية لمحصول الطماطم الثتوى فى العام السابق حيث بلغت مرونة استجابة عرض الطماطم الثتوى نحو

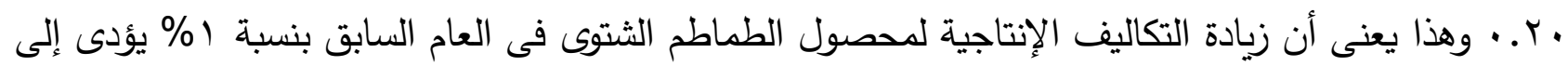




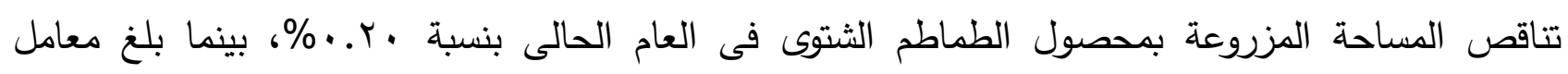
الاستجابة السنوى حوالى 9 . . ، وبلغت الفترة اللازمة لتحقيق الاستجابة الكاملة لدى المزارع حوالى ؟ ا. أنة بدءاً من العام التالى للزراعة، وهذا يعنى أنه لا يمكن التوسع فى مساحة محصول الطماطم الشتوى إلا بعد مرور أكثر من عام حتى تتحقق الاستجابة بالتوسع فى المساحة المزروعة بالمحصول. وتثير نتائج تقدير دوال استجابة العرض باستخدام بعض متغيرات المحاصيل المنافسة لمحصول الطماطم الشتوى بالنسبة لنموذج الأسعار فقد تبين وجود علاقة طردية بين المساحة المزروعة بالطماطم الشتوى فى العام الحالى والسعر المزرعى لمحصول القهح فى العام السابق، ووجود علاقة عكسية بين مساحة الطماطح الشتوى بالعام الحالى والسعر المزرعى لمحصول البسلة الخضراء فى العام السابق. أما بالنسبة لنموذج التكاليف فقد تبين وجود علاقة طردية بين المساحة المزروعة بالطماطم الثتوى فى العام الحالى والتكاليف الإنتاجية لمحصول القمح فى العام السابق، ووجود علاقة عكسية بين مساحة الطماطح الثتوى بالعام الحالى والتكاليف الإنتاجية لمحصولى البرسيم التحري والكوسة فى العام السابق. أما بالنسبة لنموذج صافى العائد الفذانى فقد تبين وجود علاقة طردية بين المساحة المزروعة بالطماطم الثتوى فى العام الحالى وصافى العائد الفدانى لمحصولى القمح والفلفل فى العام السابق، ووجود علاقة عكسية بين مساحة الطماطم الثتوى بالعام الحالى وصافى العائد الفدانى لمحصولى الباذنجان والبسلة الخضراء فى العام السابق. مقدمة:

يعتبر محصول الطماطم من أهم محاصيل الخضر فى مصر حيث يحظى باهتمام كبير من قبل الدولة والمزارع والمستهلك، حيث تعتبره الدولة من أهم محاصيل الخضر الاستراتيجية التى تساهم بشكل كبير فى سد الفجوة الغذائية نتيجة الزيادة السكانية وتحقيق الأمن الغذائى، كما يعتمد عليه المستهلك المصرى بصفة أساسية فى غذائية اليومى لما تمثله من قيمة غذائية كبيرة حيث تحتوى ثمار الطماطم على أملاح وفيتامينات وأحماض عضوية ذات أهمية غذائية كبيرة. وتعد الطماطم من محاصيل الخضر الهامة فى التركيب المحصولى المصرى باعتبارها من المحاصيل الغذائية والتصنيعية التى تقوم عليها بعض الصناعات الغذائية، ومصدراً هاماً من مصادر الدخل الزراعى القومى والحصول على النقد الأجنبى اللازم لدفع عجلة التنمية الاقتصادية من خلال مساهمتها فى حصيلة الصادرات الزراعية المصرية. ويعتبر محصول الطماطم من أهم محاصيل الخضر من حيث أهميته الإنتاجية والاستهاكية على حد سواء هذا وقد بلغت المساحة المزروعة بمحصول الطماطم

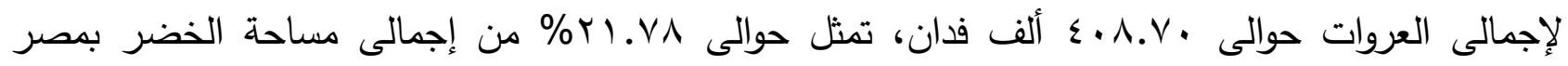
والبالغ حوالى ^^ــ ا مليون فدان عام 9 ( ـ ب. وتزرع الطماطم المصرية فى عروات ثلاثة هى الصيفية، الثتوية 


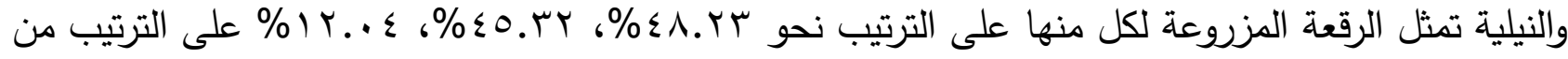
مساحة الطماطم لإجمالى العروات خلال عام 9 1. ب.

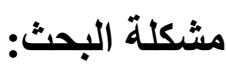

نظراً للتغيرات الاقتصادية التى واجىت القطاع الزراعى المصرى فى الأونة الأخيرة وترك الأسعار حرة تتحدد وفقاً لتفاعل قوى العرض والطلب، وإعطاء الحرية الكاملة للمزارع فى زراعة وتسويق المحاصيل وشراء مستلزمات الإنتاج، الأمر الذى يؤدى بلا شك إلى إختلاف درجة إستجابة المزارع للمتغيرات الاقتصادية المؤثرة على إستجابة العرض فى مصر بصة عامة طبقاً لسيادة آليات السوق.

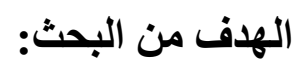

يهدف هذا البحث إلى دراسة المؤشرات الإنتاجية والاقتصادية وتقدير دوال استجابة العرض لمحصول الطماطم الثتوى فى مصر، وذلك للوقوف على أهم العوامل الاقتصادية المؤثرة على المساحة المزروعة لهذا

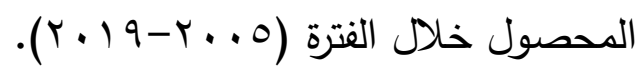
الطريقة البحثية ومصادر البيانات:

اعتمد البحث على أسلوبى التحليل الوصفى والكمى حيث تم استخدام اسلوب الانحدار الخطى البسيط لتقدير الاتجاهات الزمنية العامة لبعض الظواهز الإنتاجية والاقصادية المرتبطة بمحصول الطماطم الثتوى فى مصر ، بالإضافة إلى تطبيق نموذج مارك نيرلوف الديناميكى فى تقدير دالة استجابة العرض للوقوف على أهم المتغيرات المؤثرة على المساحة المزروعة بمحصول الطماطم الثتوى فى مصر، وذلك باستخدام اسلوب الانحدار المتعدد والمتعدد المرحلى Stepwise فى الصورتين الخطية واللوغارتمية المزدوجة، ولقد اعتمد البحث على البيانات الثانوية المنشورة التى تم تجميعها من نشرة الاحصاءات الزراعية التى تصدر من قطاع الثئون الاقتصادية بوزارة الزراعة واستصلاح الأراضى.

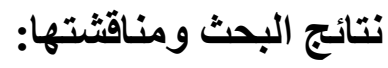
أولاً: تطور المؤشرات الإنتاجية لمحصول الطماطم لإجمالى العروات فى مصر:

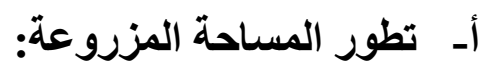

تبين من البيانات الواردة بالجدول رقم (1) أن متوسط المساحة المزروعة بمحصول الطماطم لإجمالى

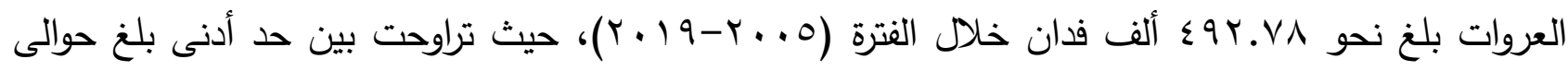

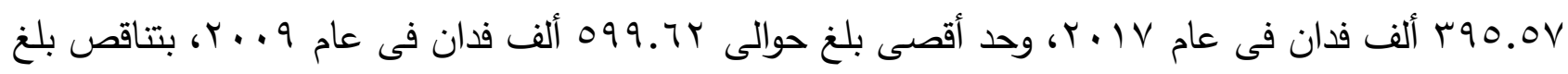

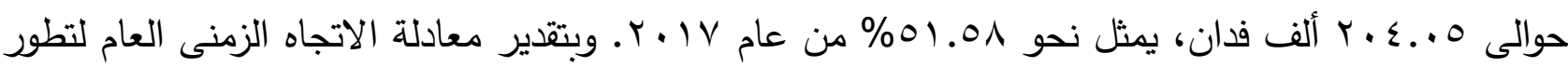


المساحة المزروعة بمحصول الطماطم لإجمالى العروات، تبين من المعادلة رقم (1) الواردة بالجدول رقم (r) تناقص المساحة المزروعة بمحصول الطماطم لإجمالى العروات بمقدار معنوى إحصائيا بلغ نحو •ـ.. أ ألف

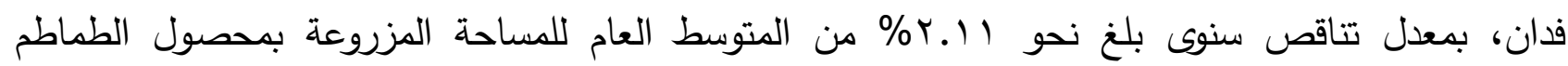

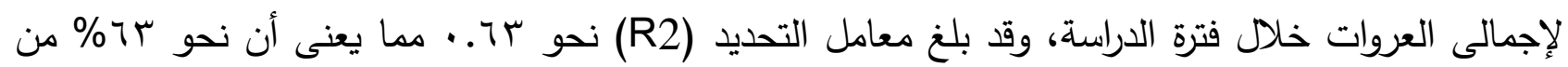
التغيرات الحادثة فى المساحة المزروعة بحصول الطماطم لإجمالى العروات ترجع إلى العوامل التى يعكسها

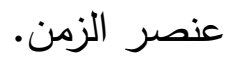

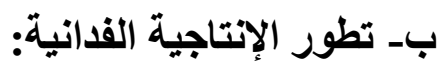

توضح البيانات الواردة بالجدول رقم (1) أن متوسط الإنتاجية الفدانية لمحصول الطماطم لإجمالى

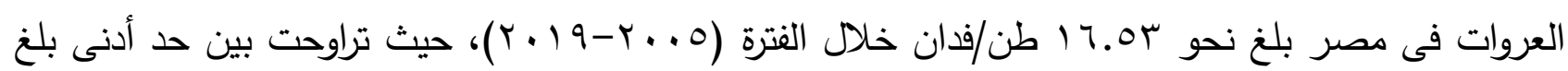

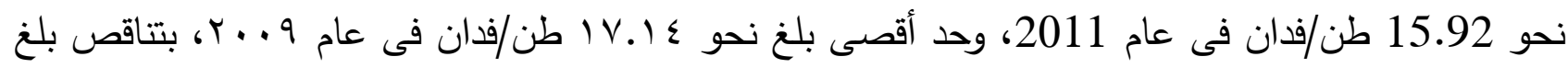

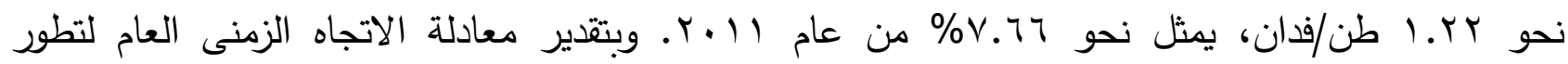
الإنتاجية الفدانية لمحصول الطماطم لإجمالى العروات فى مصر، تبين من المعادلة رقم (r) الواردة بالجدول

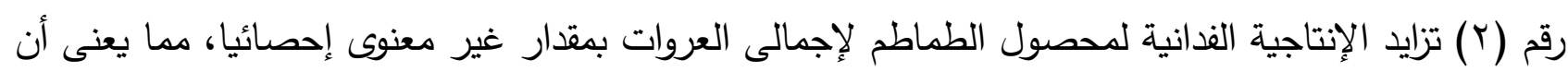
الإنتاجية الفدانية لمحصول الطماطم لإجمالى العروات تدور حول المتوسط الحسابى خلال فترة الدراسة.

\begin{tabular}{|c|c|c|c|c|c|c|}
\hline \multicolumn{3}{|c|}{ العروة الثتوى } & \multicolumn{3}{|c|}{ إجمالي العروات } & \multirow[b]{2}{*}{ السنوات } \\
\hline (ألف طأن) & (طن/فذاني) & (ألف فدانة) & (ألف طن) & (طن/فذاني) & (ألف فـانة) & \\
\hline 3977.32 & 18.53 & 214.62 & 8391.22 & 16.94 & 495.38 & 2005 \\
\hline 3814.08 & 18.24 & 209.09 & 8576.07 & 16.36 & 524.07 & 2006 \\
\hline 3623.45 & 18.09 & 200.29 & 8639.02 & 16.08 & 537.21 & 2007 \\
\hline 3853.55 & 17.69 & 217.89 & 9204.10 & 16.10 & 571.84 & 2008 \\
\hline 4929.01 & 18.58 & 265.24 & 10278.54 & 17.14 & 599.62 & 2009 \\
\hline 3760.04 & 18.39 & 204.42 & 8544.99 & 16.59 & 515.20 & 2010 \\
\hline 3487.35 & 16.75 & 208.19 & 8053.70 & 15.92 & 505.82 & 2011 \\
\hline 3707.42 & 17.82 & 208.07 & 8571.05 & 16.64 & 515.23 & 2012 \\
\hline 3670.98 & 18.20 & 201.69 & 8269.25 & 16.92 & 488.75 & 2013 \\
\hline 3387.59 & 17.33 & 195.50 & 8264.54 & 16.22 & 509.56 & 2014 \\
\hline 3308.51 & 17.68 & 187.14 & 7727.22 & 16.49 & 468.51 & 2015 \\
\hline 3329.78 & 17.96 & 185.38 & 7311.17 & 16.61 & 440.23 & 2016 \\
\hline
\end{tabular}




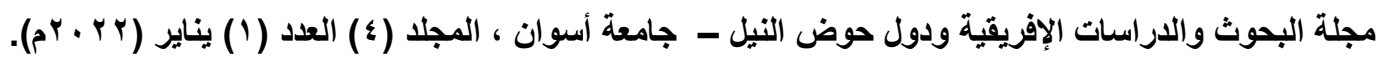

\begin{tabular}{|c|c|c|c|c|c|c|}
\hline 3090.90 & 18.30 & 168.88 & 6723.25 & 17.00 & 395.57 & 2017 \\
\hline 2953.99 & 17.26 & 171.11 & 6770.75 & 16.27 & 416.03 & 2018 \\
\hline 3268.74 & 17.65 & 185.21 & 6793.69 & 16.62 & 408.70 & 2019 \\
\hline 3610.85 & 17.90 & 201.51 & 8141.24 & 16.53 & 492.78 & المتوسط \\
\hline
\end{tabular}

جدول رقم (1 ): تطور المساحة المزروعة والإنتاجية الفدانية والإنتاج الكلى لمحصول الطماطم للعروات المختلفة فى مصر

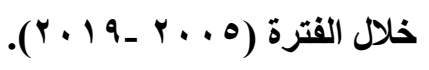

المصدر: جمعت وحسبت من: وزارة الزر اعة واستصلاح الأر اضى، قطاع الثشئون الاقتصادية، الإدارة المركزية للاقتصاد الزراعى، نشرة الاقتصاد الزر اعى، أعداد متفرقة.

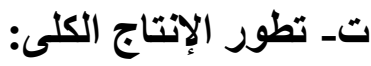

تبين من البيانات الواردة بالجدول رقم (1) أن متوسط الإنتاج الكلى لمحصول الطماطم لإجمالى

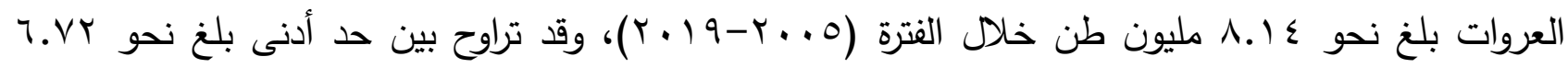

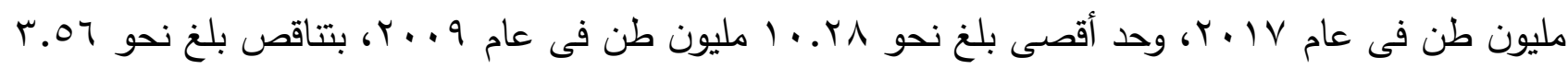

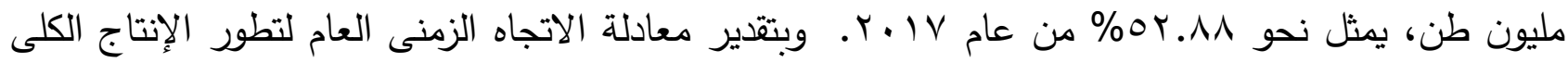
لمحصول الطماطم لإجمالى العروات فى مصر ، تبين من الدعادلة رقم (r) الواردة بالجدول رقم (Y) تناقص الإنتاج الكلى لمحصول الطماطم لإجمالى العروات بمقدار معنوى إحصائيا بلغ نحو 0ـ ـ17 ألف طن، بمعدل

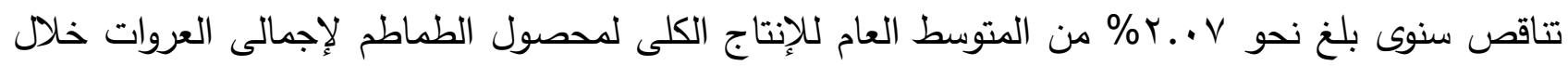

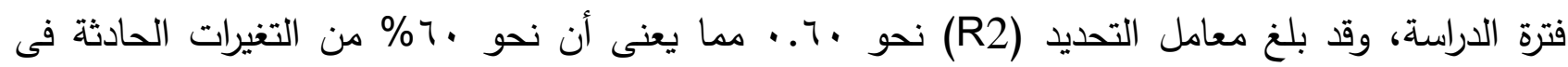
الإنتاج الكلى لمحصول الطماطم لإجمالى العروات ترجع إلى العوامل التى يعكسها عنصر الزمن.

\begin{tabular}{|c|c|c|c|c|c|c|}
\hline معدل التغير (\%) & $\mathbf{F}$ & $\mathbf{R}^{2}$ & معادلات الإتجاه الزمنى العام & متغيرات الدراسة & p & العروة \\
\hline r.11- & 22.37 & r & 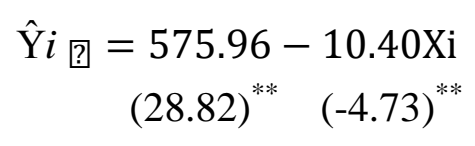 & المساحة المزروعة (ألف فدان) & 1 & \\
\hline- &. $.1 \mathrm{r}$ & $\because \cdot 1$ & $\begin{array}{c}\hat{Y} i_{\text {回 }}=16.47+0.01 \mathrm{Xi} \\
(79.68)^{* *}(0.34)^{-}\end{array}$ & الإنتاجية الفدانية (طن/فدان) & r & إلعروات \\
\hline$r_{.} \cdot v_{-}$ & $19 . \wedge \varepsilon$ & .7. & $\begin{aligned} \hat{Y} i_{\text {回 }}= & 9488.80 \\
& -168.45 X i \\
& (27.60)^{* *}(-4.46)^{* *}\end{aligned}$ & الإنتاج الكلى (ألف طن) & $r$ & \\
\hline
\end{tabular}




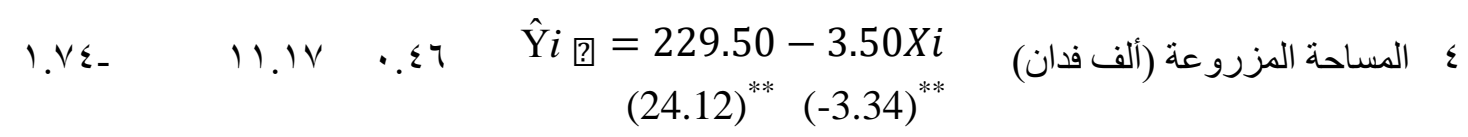

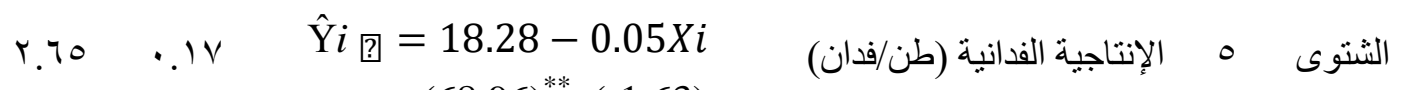

צ $(22.06)^{* *}(-3.47)^{* *}$

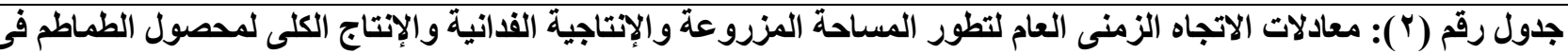

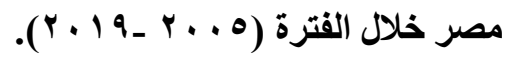

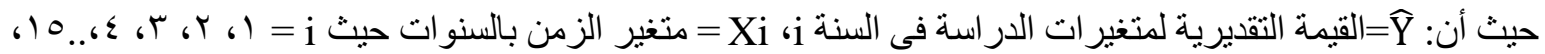

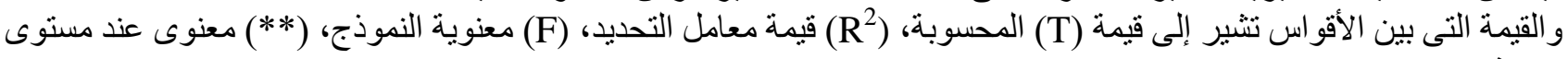

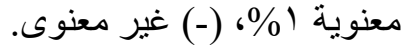

المصدر: حسبت من البيانات الو اردة بالجدول رقم ( (1).

ثانياً: تطور المؤشرات الإنتاجية لمحصول الطماطم الشتوى فى مصر:

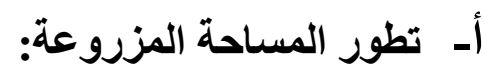

تشير البيانات الواردة بالجدول رقم (1) إلى أن متوسط المساحة المزروعة بمحصول الطماطح الثتوى

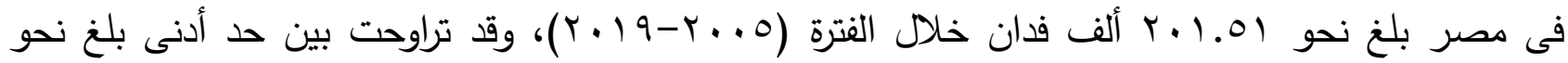

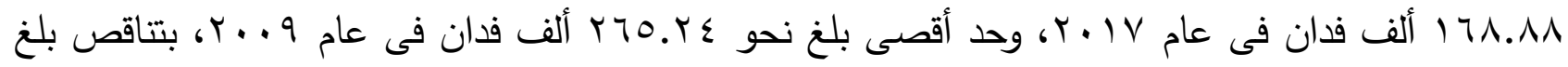

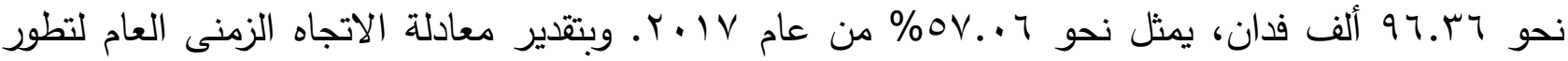
المساحة المزروعة بمحصول الطماطم الشتوى فى مصر، تبين من المعادلة رقم (ع) الواردة بالجدول رقم (r) تناقص المساحة المزروعة بمحصول الطماطم الشتوى بمقدار معنوى إحصائيا بلغ نحو ـ. ألف فدان، بمعدل تناقص سنوى بلغ نحو § \. (\% من المتوسط العام للمساحة المزروعة بمحصول الطماطم الشتوى خلال فترة

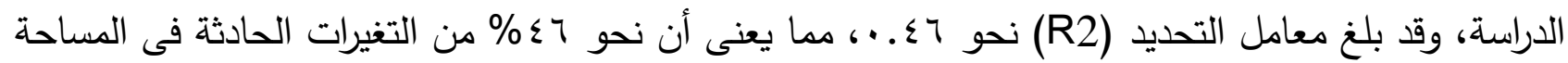
المزروعة بمحصول الطماطم الثتوى ترجع إلى العوامل التى يعكسها عنصر الزمن. ب- تطور الإنتاجية الفدانية:

توضح البيانات الواردة بالجدول رقم (1) أن متوسط الإنتاجية الفدانية لمحصول الطماطم الثتوى فى

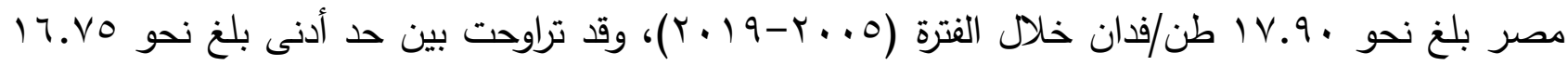

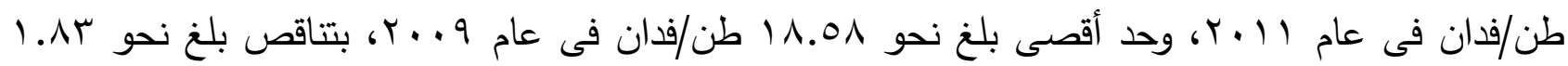
طن/فدان، يمثل نحو ب9. • (\% من عام || ـ . وبتقدير معادلة الاتجاه الزمنى العام لتطور الإنتاجية الفدانية لمحصول الطماطم الثتوى فى مصر، تبين من المعادلة رقم (0) الواردة بالجدول رقم (Y) تتاقص الإنتاجية 
الفذانية لمحصول الطماطم الثتوى بمقدار غير معنوى إحصائيا، مما يعنى أن الإنتاجية الفدانية لمحصول الطماطم الثتوى تدور حول المتوسط الحسابى خلال فترة الدراسة.

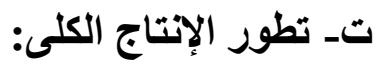

تبين من البيانات الواردة بالجدول رقم (1) أن متوسط الإنتاج الكلى لمحصول الطماطم الثتوى فى

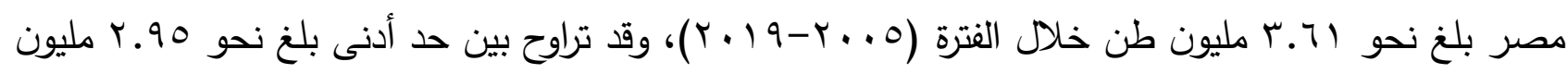

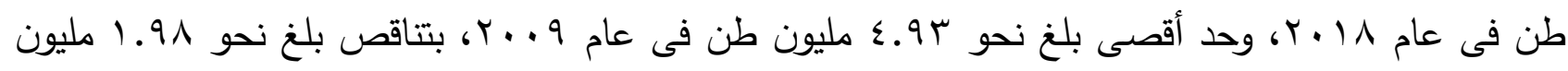

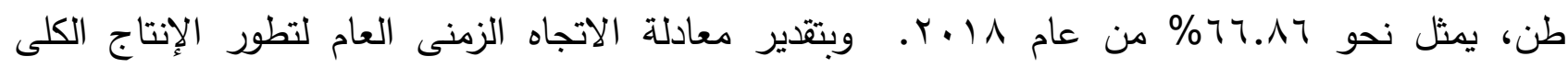

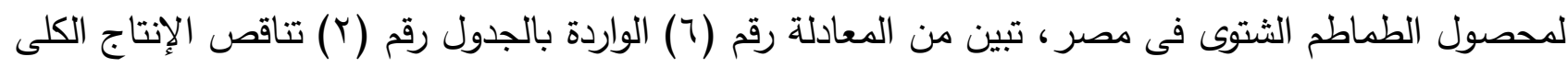
لمحصول الطماطم الثتوى بمقدار معنوى إحصائيا بلغ نحو VY.O ألف طن، بمقدار تناقص سنوى بلغ نحو

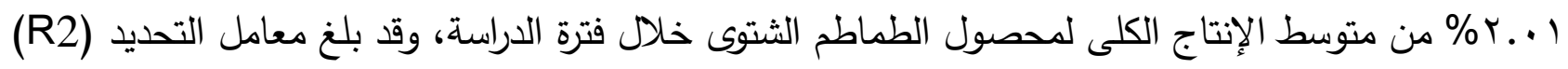
نحو ^^ء..، مما يعنى أن نحو ^^؛ \% من التغيرات الحادثة فى الإنتاج الكلى لمحصول الطماطم الشتوى ترجع إلى العوامل التى يعكسها عنصر الزمن. ثالثاً: تطور المؤشرات الاقتصادية لمحصول الطماطم الثتوى: لزعن

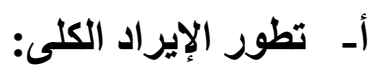

يتبين من البيانات الواردة بالجدول رقم (r) تبين أن متوسط الإيراد الكلى لمحصول الطماطم الثتوى فى

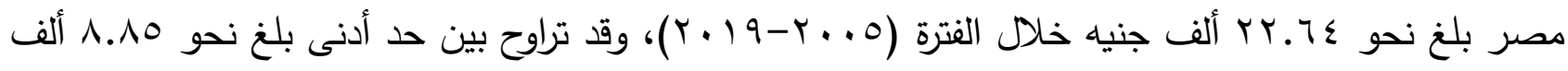

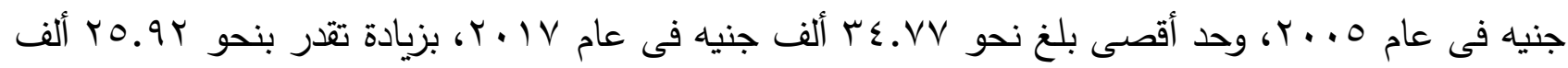

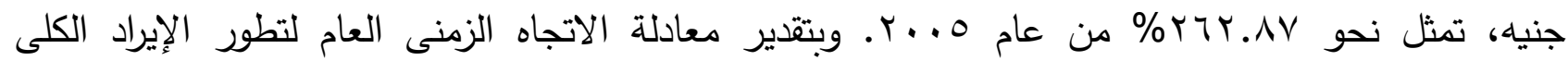
لمحصول الطماطم الثتوى فى مصر، تبين من المعادلة رقم (1) الواردة بالجدول رقم (ع) تزايد الإيراد الكلى لمحصول الطماطم الثتوى بمقدار معنوى إحصائيا بلغ نحو 10.19 19 جنيه، بمعل زيادة سنوى بلغ نحو

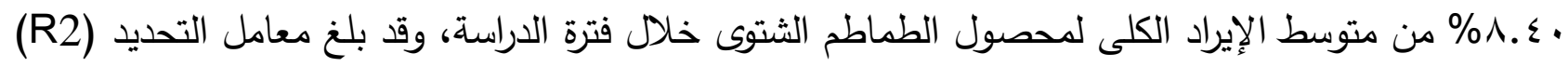

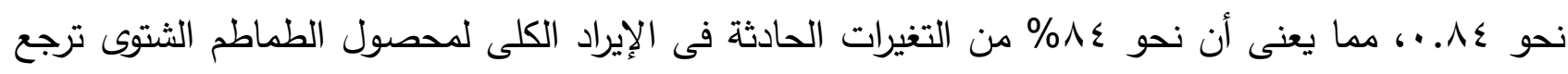
إلى العوامل التى يعكسها عنصر الزمن. بـ تطور التكاليف الإنتاجية الفدانية:

توضح البيانات الواردة بالجدول رقم (r) أن متوسط التكاليف الإنتاجية الفدانية لـحصول الطماطم

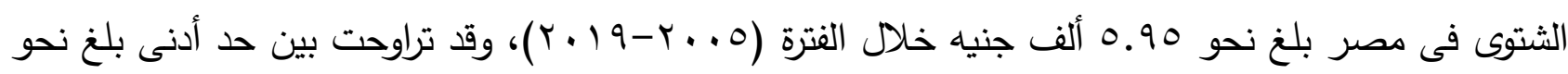




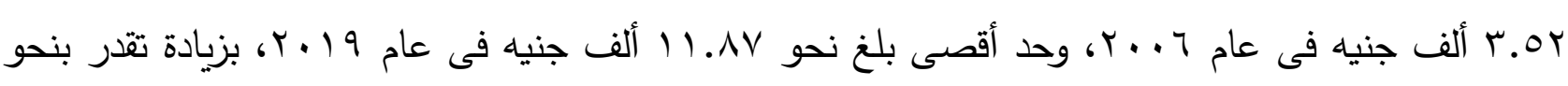

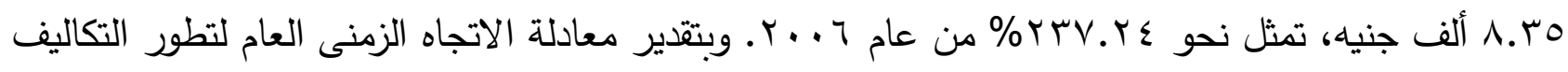
الإنتاجية الفدانية لمحصول الطماطم الثتوى فى مصر ، تبين من المعادلة رقم (Y) الواردة بالجدول رقم (ع) تزايد

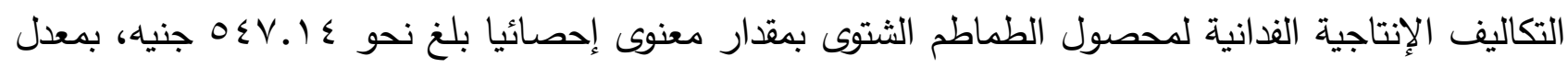
زيادة سنوى بلغ نحو ..9\% من متوسط التكاليف الإنتاجية الفدانية لمحصول الطماطم الشتوى خلال فترة الدراسة، وقد بلغ معامل التحديد (R2) نحو (N) . ، مما يعنى أن نحو IN\% من التغيرات الحادثة فى التكاليف الإنتاجية الفدانية لمحصول الطماطم الثتوى ترجع إلى العوامل التى يعكسها عنصر الزمن.

\section{تـ تطور صافي العائد الفدانى:}

يتبين من البيانات الواردة بالجدول رقم (r) أن متوسط صافى العائد الفدانى لمحصول الطماطم الشتوى

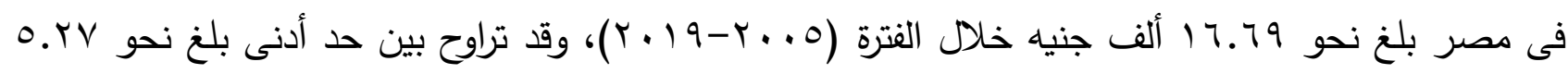

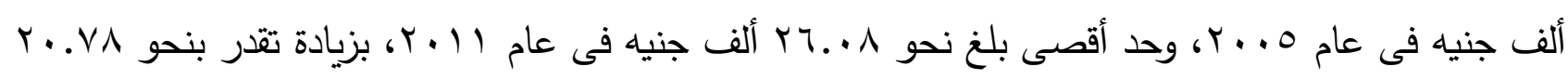

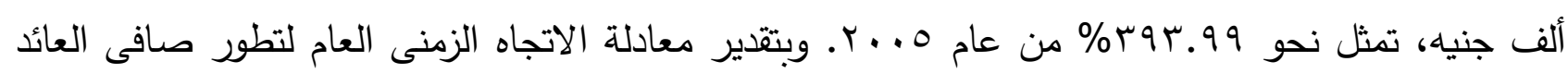
الفدانى لمحصول الطماطم الشتوى فى مصر، تبين من المعادلة رقم (ب) الواردة بالجدول رقم (ع) تزايد صافى

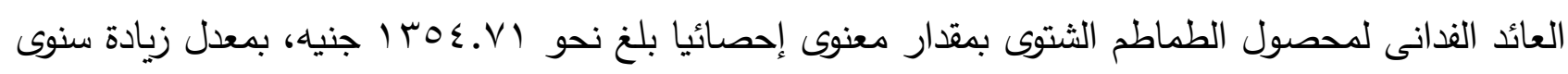
بلغ نحو 1/1\% من متوسط صافى العائد الفدانى لمحصول الطماطح الشتوى خلال فترة الدراسة، وقد بلغ معامل التحديد (R2) نحو جا7. .، مما يعنى أن نحو 7r\% من التغيرات الحادثة فى صافى العائد الفدانى

لمحصول الطماطم الثتوى ترجع إلى العوامل التى يعكسها عنصر الزمن.

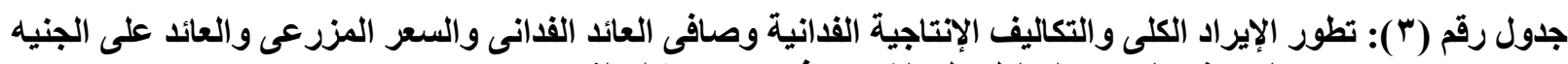

\begin{tabular}{|c|c|c|c|c|c|}
\hline المستثمر (") (جنيه) & السعر المزرعى (جنيه/فدان) & صافى العائد الفدانى & التكاليف الإنتاجية الفدانية & (الإيراد الكلى & السنوات \\
\hline 1.47 & 466 & 5273 & 3576 & 8849 & r..o \\
\hline 2.28 & 611 & 8022 & 3520 & 11542 & $r \ldots r$ \\
\hline 2.19 & 633 & 8140 & 3710 & 11850 & $r \ldots r$ \\
\hline 2.93 & 845 & 11622 & 3960 & 15582 & $r \ldots \Lambda$ \\
\hline 1.54 & 547 & 6662 & 4318 & 10980 & $r \ldots q$ \\
\hline 2.18 & 712 & 9664 & 4434 & 14098 & $r \cdot 1$. \\
\hline 5.79 & 1737 & 26048 & 4499 & 30547 & $r .11$ \\
\hline
\end{tabular}




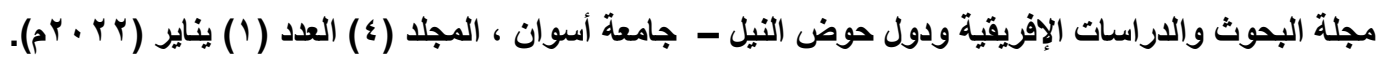

\begin{tabular}{|c|c|c|c|c|c|}
\hline 4.50 & 1474 & 21683 & 4817 & 26500 & $r \cdot I r$ \\
\hline 4.42 & 1485 & 22134 & 5006 & 27140 & $r .1 T$ \\
\hline 3.91 & 1490 & 20994 & 5370 & 26364 & $r \cdot 1 \leq$ \\
\hline 3.74 & 1540 & 21947 & 5867 & 27814 & $r .10$ \\
\hline 2.36 & 1462 & 19542 & 8267 & 27809 & $r .17$ \\
\hline 2.75 & 1755 & 25501 & 9264 & 34765 & $r+I V$ \\
\hline 1.96 & 1771 & 21033 & 10705 & 31738 & $r \cdot 11$ \\
\hline 1.87 & 1840 & 22154 & 11871 & 34025 & $r .19$ \\
\hline 2.93 & 1224.53 & 16694.60 & 5945.60 & 22640.20 & المتوسط \\
\hline
\end{tabular}

جدول رقم (؛) ): معادلات الاتجاه الزمنى العام لتطور الإيراد الكلى والتكاليف الإنتاجية الفدانية وصافي العائد الفدانى والسعر المزرعى

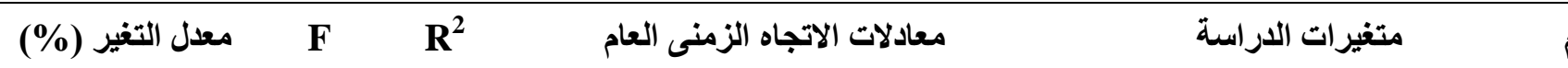

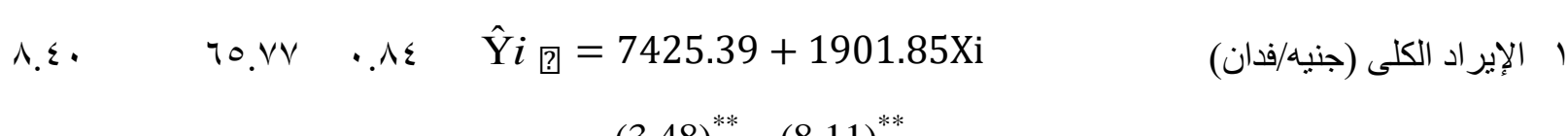

$(3.48)^{* *}(8.11)^{* *}$

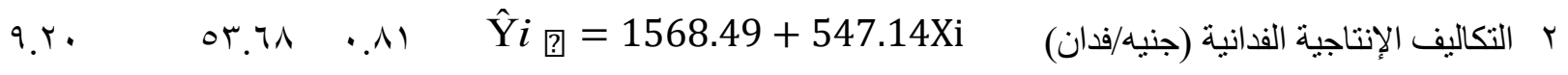
$(2.30)^{*}(7.36)^{* *}$

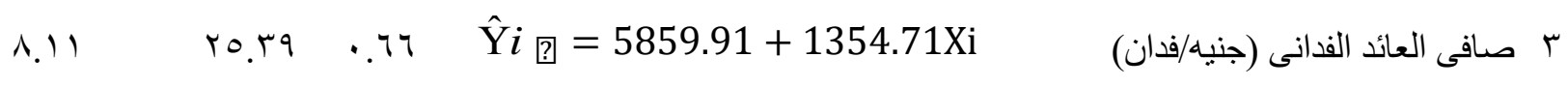
$(2.40)^{*}(5.04)^{* *}$

؛.

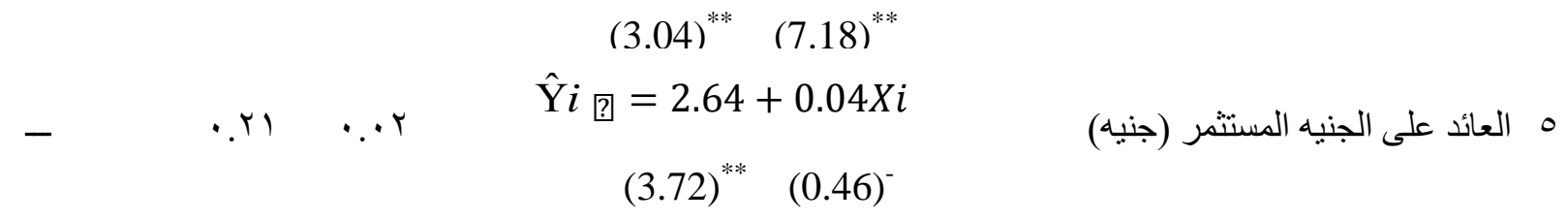

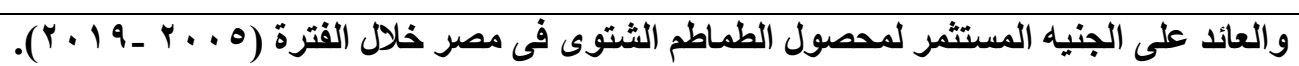

حبث أن:

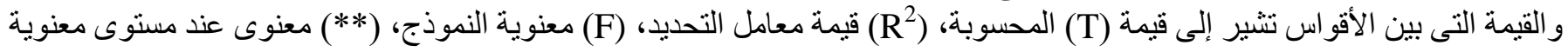

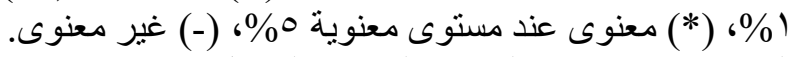

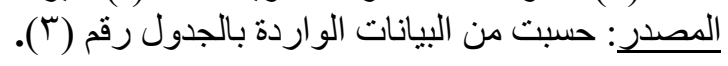


تبين من البيانات الواردة بالجدول رقم (r) أن متوسط السعر المزرعى لمحصول الطماطم الثتوى فى

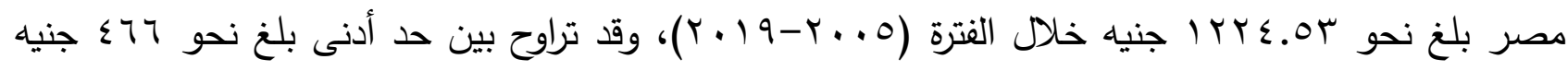

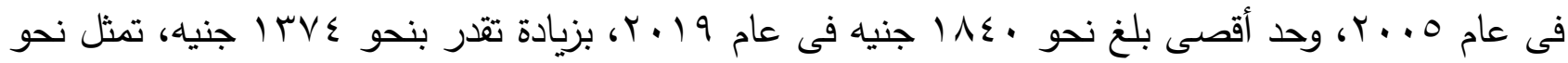

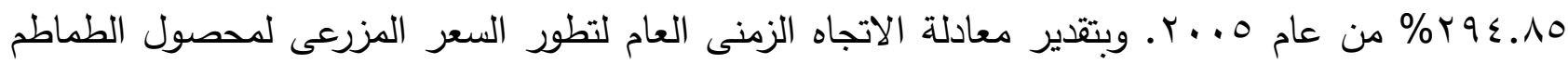
الثتوى فى مصر، تبين من المعادلة رقم (£) الواردة بالجدول رقم (؟) تزايد السعر المزرعى لمحصول الطماطم

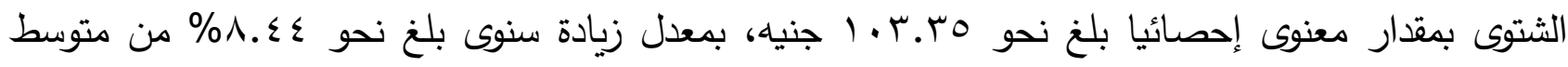
السعر المزرعى لمحصول الطماطم الثتوى خلال فترة الدراسة، وقد بلغ معامل التحديد (R2) نحو •^...، مما يعنى أن نحو •^^\% من التغيرات الحادثة فى السعر المزرعى لدحصول الطماطم الثتوى ترجع إلى العوامل

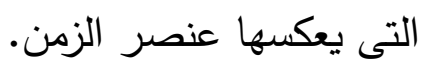

\section{ج- تطور العائد على الجنيه المستثمر: - (ل)}

توضح البيانات الواردة بالجدول رقم (r) أن متوسط العائد على الجنيه المستثر لمحصول الطماطم

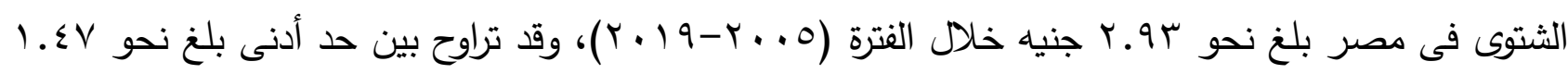

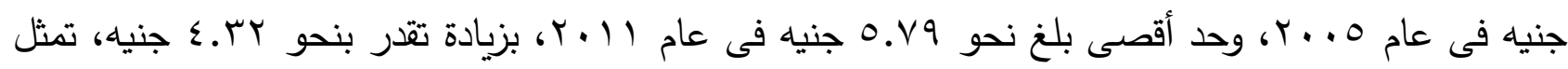

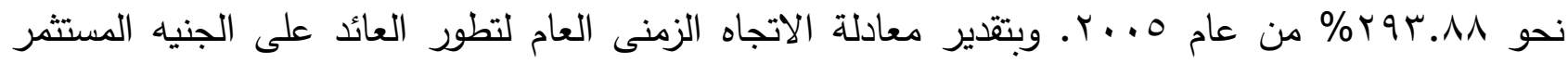
لمحصول الطماطم الثتوى فى مصر، تبين من المعادلة رقم (0) الواردة بالجدول رقم (ع) تزايد العائد على الجنيه المستثمر لمحصول الطماطم الثتوى بمقدار سنوى غير معنوى إحصائيا، مما يعنى أن العائد على الجنيه المستثمر لمحصول الطماطم الثتوى يدور حول المتوسط الحسابى خلال فترة الدراسة. رابعاً: التقدير الإحصائى لدوال استجابة عرض محصول الطماطم الشتوى فى مصر:

لتقدير استجابة العرض لمحصول الطماطم الثتوى تم استخدام نموذج Mark nerlove الديناميكى الذى يعتبر من أفضل النماذج تمثيلا لاستجابة عرض محصول الطماطم الثتوى ومن خلاله أمكن دراسة العلاقة بين المساحة المزروعة بالمحصول فى السنة (t) كعامل تابع، وأهم المتغيرات التفسيرية فى السنة السابقة (t - 1 (1)، والتى تقترض تأثيرها على العامل التابع، حيث يوضح النموذج أن المزارعين يستجيبون ليس لسعر

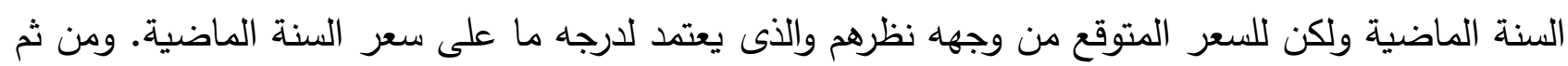
يعتدد النموذج على قيام الزراع بتعديل توقعاتهم السعرية وفقا لنسبة الخطأ الذى حدث فى توقعاتهم لأسعار السنه 
السابقة. ولقد اعتمد النموذج المستخدم فى البحث على أثث التغيرات السعرية فضلا عن اثر المتغيرات الأخرى التى افترض البحث تأثيرها على المساحة المزروعة فى السنه (t) كمتغير تابع ولقد تم استبعاد بعض المتغيرات المستقلة المفترض تأثيرها على المتغير التابع طبقا لدرجة الارتباط الخطى البسيط بين بعضها البعض من خلال مصفوفة الارتباط، هذا وقد تم استخدام نموذج تحليل الانحدار المتعدد المراحل stepwise وذلك للحد من الأثار السلبية للازدواج الخطى على دقه التقديرات الإحصائية للنموذج. ولقد تم تقدير دالة استجابة العرض لمحاصيل الدراسة باستخدام الصيغتين الخطية واللوغاريتمية المزدوجة التاليتين:

$$
\begin{aligned}
\hat{Y} & =a \pm b_{1} X_{1(t-1)} \pm b_{2} X_{2(t-1)} \pm b_{3} X_{3(t-1)} \pm \cdots \ldots \ldots \ldots \ldots \pm b_{n} X_{n(t-1)} \\
\ln \hat{Y} & =a \pm b_{1} \ln X_{1(t-1)} \pm b_{2} \ln X_{2(t-1)} \pm b_{3} \ln X_{3(t-1)} \pm \cdots \ldots \pm b_{n} \ln X_{n(t-1)}
\end{aligned}
$$

حيث تثبر y العامل التابع فى الدالة المقدرة سو اء كانت خطية أو لو غاريتميـة مزدوجـة إلى المسـاحة

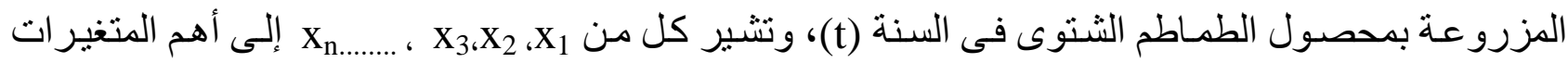

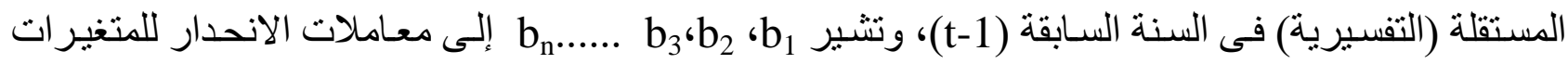
التفسيرية.

واعتمدت الدراسة فى تقدير دوال استجابة العرض على محورين أساسيين هما: الأول استخدام نموذج مارك نيرلوف الديناميكى باعتباره من أشهر النماذج الاقتصادية فى تقدير دوال استجابة العرض، وذلك نظراً لسهولة تقديره وإمكانية إدخال العديد من المتغيرات المستقلة فى تلك الدالة. حيث افترض البحث أن استجابة مساحة المحصول فى العام الحالى تتأثر ببعض المتغيرات المرتبطة بالمحصول بفترة تأخير عام واحد، متمثلة فى الإنتاجية الفدانية، السعر المزرعى، التكاليف الإنتاجية، صافى العائد الفدانى، مع حساب مرونة استجابة العرض فى الددى القصير، بالاضافة إلى حساب معامل الاستجابة السنوى والفترة اللازم انقضاؤها لتحقق الاستجابة الكاملة لدى المزارع بدءاً من العام التالى للزراعة. أما المحور الثانى فتضمن دراسة استجابة العرض لمساحة المحصول فى العام الحالى تتأثر ببعض متغيرات والمتمثلة فى الأسعار المزرعية، التكاليف الإنتاجية، صافى العائد الفدانى للمحاصيل المنافسة. حيث تم تقدير دوال استجابة العرض لمحصول الطماطم الثتوى باستخدام النموذج الخطى واللوغاريتمى المزدوج، وذلك بعد مقارنة الدوال المقدرة واختيار أفضلها من حيث معنويتها الإحصائية ومعنوية النموذج ومعنوية المتغيرات ومنطقية إثارة المعاملات فضلا عن تمشيها مع المنطق الاقتصادى والإحصائى. وللوصول لأفضل النماذج تم إجراء العديد من المحاولات لتقدير العوامل المحددة للمساحة المزروعة بالمحصول وذلك بعد عمل مصفوفة الارتباط البسيط بين جميع العوامل الداخلة فى الدراسة. ونظراً لكبر عدد المتغيرات المستقلة بالنسبة لعدد السنوات بما يتافى مع شروط الانحدار المتعدد من ناحية، ومنعاً للوقوع فى أى من مشاكل القياس الاقتصادى 
وبصفة خاصة مشكلة الازدواج الخطى بين المتغيرات من ناحية أخرى. فقد تم تقسيم العوامل التفسيرية إلى ثلاث مجموعات الأولى مجموعة المتغيرات الخاصة بالأسعار المزرعية للمحاصيل المنافسة، والثانية مجموعة المتغيرات الخاصة بالتكاليف الإنتاجية للمحاصيل المنافسة، والثالثة مجموعة المتغيرات الخاصة بصافى العائد الفذانى للمحاصيل المنافسة. 1- التقدير الإحصائى لدوال استجابة العرض للمتغيرات المرتبطة بالمحصول:

تم تقدير دوال استجابة العرض باستخدام نموذج مارك نيرلوف المعدل والذى يعتمد على قياس العلاقة

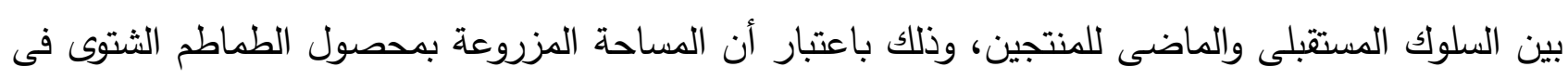
Y(t-) العام الحالى (Yt) دالة فى المساحة المزروعة من هذا المحصول فى العام السابق بفترة تأخير عام واحد (1) (1) ومع كل من: (1) (1) الإلتاجية الفدانية لمحصول الطماطم الثتوى بالطن فى العام السابق. السعر المزر عى لمحصول الطماطم بالجنيه فى العام السابق. التكاليف الإنتاجية الفدانية لمحصول الطماطم بالجنيه فى العام السابق. (X) = $=\left(X_{4(-1)}\right)$

تشير النتائج الواردة بالجدول رقم (0) إلى دوال استجابة عرض محصول الطماطم الثتوى باستخدام نموذج مارك نيرلوف الديناميكى المعدل، حيث توضح المعادلة رقم (1) استجابة المزارع للإنتاجية الفدانية لمحصول الطماطم الثتوى فى العام السابق، ويوضح معامل التحديد المعدل أن نحو بr\% من التغيرات

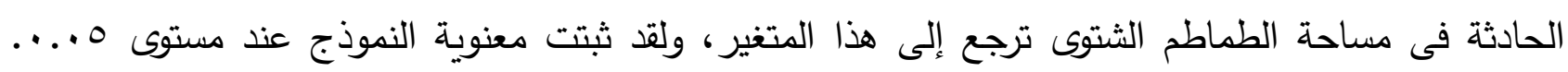
وتوضح النتائج أن زيادة الإنتاجية الفدانية لمحصول الطماطم الثتوى فى العام السابق بجنيه واحد يترتب عليه

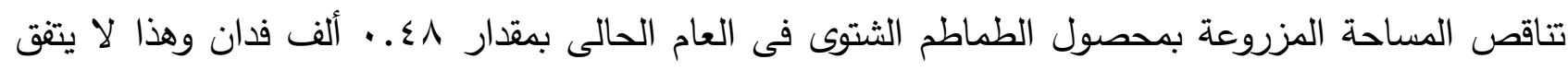

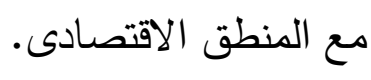

وتوضح نتائج المعادلة رقم (r) بالجدول رقم (0) استجابة المزارع للسعر المزرعى لمحصول الطماطم الثتوى فى العام السابق، يوضح معامل التحديد المعدل أن نحو 9ب\% من التغيرات الحادثة فى مساحة الطماطم الثتوى ترجع إلى هذا المتغير، قد ثبتت معنوية النموذج عند مستوى معنوية ه .... وتوضح النتائج أن زيادة السعر المزرعى لمحصول الطماطم الشتوى فى العام السابق بجنيه واحد يترتب عليه انخفاض المساحة

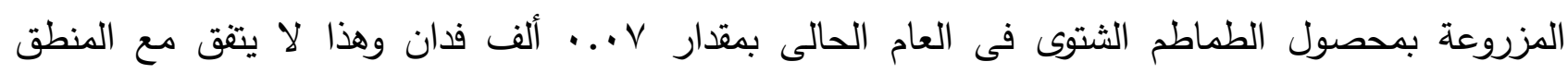


وتوضح نتائج المعادلة رقم (؟) بالجدول رقم (0) استجابة المزارع للتكاليف الإنتاجية لمحصول الطماطم الثتوى فى العام السابق، يوضح معامل التحديد المعدل أن نحو 7 ٪٪ من التغيرات الحادثة فى مساحة الطماطم الثتوى ترجع إلى هذا المتغير، قد ثبتت معنوية النموذج عند مستوى ا..... وتوضح النتائج أن زيادة

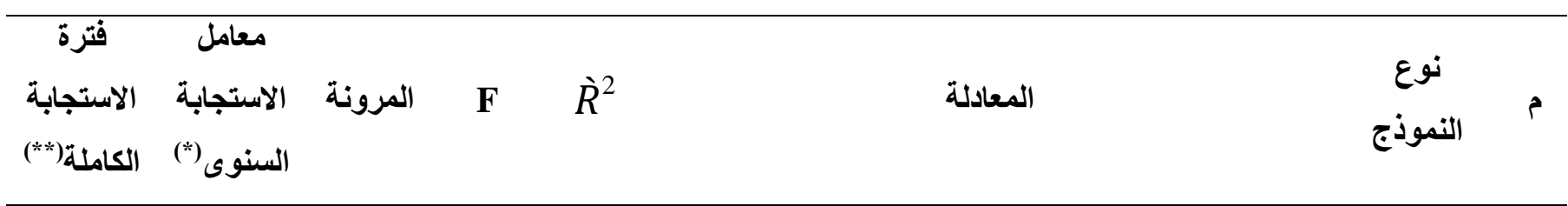

التكاليف الإنتاجية لمحصول الطماطم الثتّى فى العام السابق بجنيه واحد يترتب عليه انخفاض المساحة المزروعة بمحصول الطماطم الثتوى فى العام الحالى بمقدار ·. ... ألف فدان بافتراض ثبات باقى العوامل الأخرى عند مستوى معين، كما بلغت مرونة استجابة عرض الطماطم الثتوى نحو • ب.. وهذا يعنى أن زيادة التكاليف الإنتاجية لمحصول الطماطم الثتوى فى العام السابق بنسبة (\% يؤدى إلى تناقص المساحة المزروعة

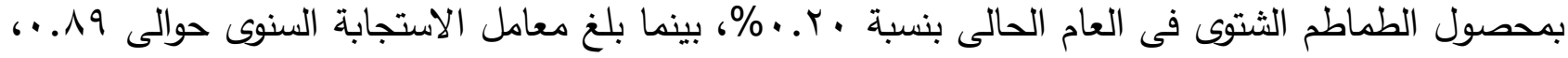
وبلغت الفترة اللازمة لتحقيق الاستجابة الكاملة لاى المزارع حوالى ب ا.ا سنة بدءاً من العام التالى للزراعة،

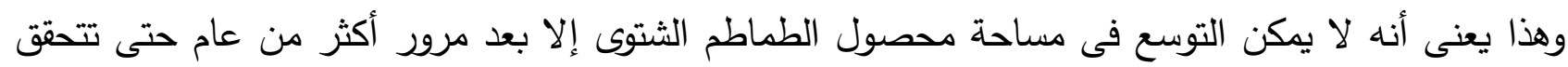
الاستجابة بالتوسع فى المساحة المزروعة بالمحصول.

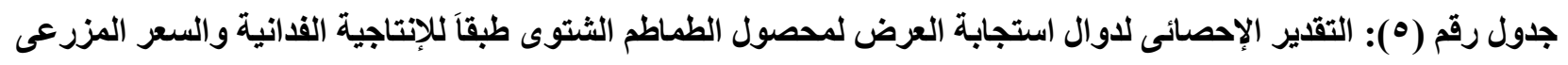

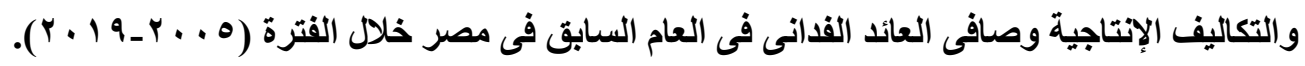


X6(t-1)

X7(t-1) السعر المزرعى لمحصول الفلفل فى العام السابق.

X8(t-1)

X9(t-1)

بعد تطبيق أسلوب تحليل الانحدار المتعدد المراحل باستخدام Stepwise تبين من الجدول رقم (؟) أن

النموذج الخطى هو أفضل النماذج لتقدير دالة استجابة العرض لمحصول الطماطم الثتوى وفقاً لقيمة معامل التحديد المعدل (F) ومعنوية النموذج (F). ويتضح من المعادلة رقم ( ) بهذا الجدول وجود علاقة طردية بين كل من المساحة المزروعة بمصصول الطماطم الشتوى بالألف فدان فى العام الحالى (كمتغير تابح) والسعر المزرعى لمحصول القـح بالجنيه فى العام السابق (1(t-1) ) . حيث بلغت مرونة استجابة العرض له حوالى זآ. . وهذا يعنى أن زيادة السعر المزرعى لمحصولى القدح فى العام السابق بمقدار ا\% يؤدى إلى زيادة المساحة المزروعة بمصصول الطماطم الشتوى فى العام التالى بمقدر بآ.•\% وهذا لا يتفق مع المنطق الاقتصادى على الرغم من معنوية المتغير عند مستوى معنوية ا..... كما يتضح من النموذج وجود علاقة عكسية منطقية اقتصادياً واحصائياً عند مستوى معنوية ا... بين كل من المساحة المزروعة بمحصول الطماطم الشتوى بالألف فدان (كمتغير تابع) والسعر المزرعى لمحصول البسلة الخضراء بالجنيه فى العام السابق (X9(t-1) حيث بلغت مرونة استجابة العرض له حوالى بآ. . وهذا يعنى أن زيادة السعر المزرعى لمحصول البسلة الخضراء فى العام السابق بمقداره (\% يؤدى إلى تناقص المساحة المزروعة بمحصول

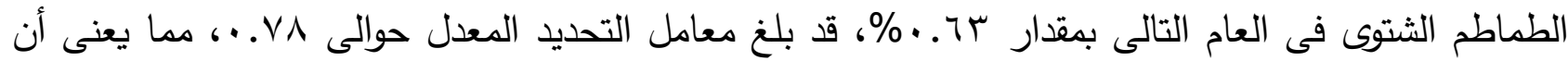
\% من التغيرات الحادثة فى المساحة المزروعة بحصصول الطماطم الثتوى ترجع إلى المتغيرات الموجودة بنموذج الاستجابة. وقد ثبت معنوية النموذج ككل عند مستوى معنوية ا.....

\begin{tabular}{|c|c|c|c|c|c|}
\hline $\mathbf{F}$ & $\grave{R}^{2}$ & المعادلات & b & النموذج & المتغيرات \\
\hline \multirow[t]{2}{*}{26.08} & $\because \vee \wedge$ & $\hat{Y}=200.24+0.37 X_{1(t-1)}-0.06 X_{9(t-1)}$ & 1 & خطي & السعر \\
\hline & & $(22.91)^{* *}$ & & 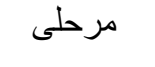 & المزرعى \\
\hline \multirow[t]{2}{*}{14.35} & $\cdot V \leqslant$ & $\ln \hat{y}=5.19+0.72 \ln X_{1(t-1)}-0.29 \ln X_{3(t-1)}-0.45 \ln X_{8(t-1)}$ & r & 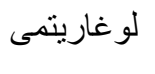 & التكاليف \\
\hline & & $(10.46)^{* *} \quad(3.56)^{* *}$ & & 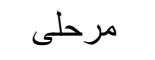 & الإنتاجية \\
\hline
\end{tabular}


بمحصول الطماطم الثتوى فى العام التالى بمقدار Vr. • \%. كما وضح النموذج وجود علاقة عكسية بين كل من المساحة المزروعة بمحصول الطماطم الثتوى بالألف فدان (كمتغير تابع) وكل من التكاليف الإنتاجية الفدانية لمحصول البرسيم التحريش بالجنيه فى العام السابق (1(-1)33) والتكاليف الإنتاجية الفدانية لمحصول

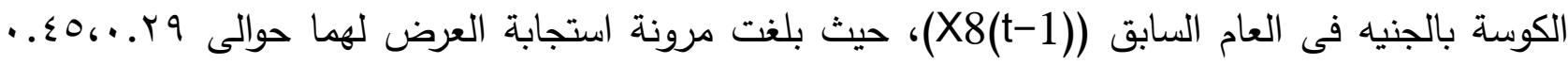
على الترتيب وهذا يعنى أن زيادة التكاليف الإنتاجية الفدانية لمحصولى برسيم التحريش والكوسة فى العام السابق

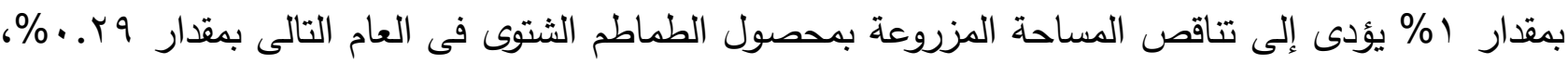
0ء. • \% على الترتيب وهذا لا يتفق مع المنطق الاقتصادى على الرغم من معنوية المتغيرين عند مستوى

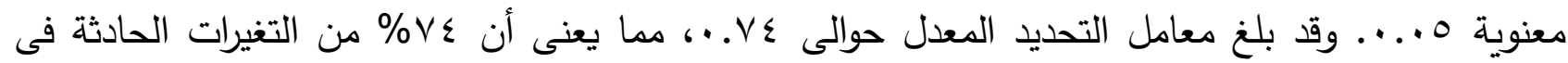
المساحة المزروعة بمحصول الطماطم الثتوى ترجع إلى المتغيرات الموجودة بنموذج الاستجابة. وقد ثبت معنوية النموذج ككل عند مستوى معنوية ا....

\section{تـ المتغيرات الخاصة بصافى العائد القدانى للمحاصيل المنافسة:}

تم تقدير دوال استجابة العرض باستخدام نموذج مارك نيرلوف المعدل وذلك باعتبار أن المساحة المزروعة بحصول الطماطم الثتوى فى العام الحالى (Yt) دالة فى صافى العائد الفدانى المحاصيل المنافسة فى العام السابق بفترة تأخير عام واحد (1-1) وهى:

X1(t-1) X2(t-1) = صافى العائد الفدانى لمحصول البرسيم المستديم فى العام السابق. X3(t-1) X4(t-1) X5(t-1) X6(t-1) X7(t-1) X8(t-1) X9(t-1)

بعد تطبيق أسلوب تحليل الانحدار المتعدد المراحل باستخدام Stepwise تبين من الجدول رقم (؟) أن النموذج الخطى هو أفضل النماذج لتقدير دالة استجابة العرض لمحصول الطماطم الثتوى وفقاً لقيمة معامل التحديد المعدل (R2) ومعنوية النموذج (F). يتضح من المعادلة رقم (ץ) بالجدول رقم (†) وجود علاقة طردية 
بين كل من المساحة المزروعة بمحصول الطماطم الثتوى بالألف فدان فى العام الحالى (كمتغير تابع) وبين صافى العائد الفدانى لمحصول القـح بالجنيه فى العام السابق (1)(t) X1(t) وصافى العائد الفدانى لمحصول الفلفل بالجنيه فى العام السابق (X7(t-1)) . حيث بلغت مرونة استجابة العرض لهما حوالى ب ا. . ، 1 (.. على الترتيب وهذا يعنى أن زيادة صافى العائد الفدانى لمحصولى القمح والفلفل فى العام السابق بمقداره يؤدى إلى زيادة المساحة المزروعة بمحصول الطماطم الشتوى فى العام التالى بمقدار ب ا. . \% 7 ا . . \% على الترتيب وهذا لا يتفق مع المنطق الاقتصادى على الرغم من معنوية المتغيرين عند مستوى معنوية ا ..... كما وضح النموذج وجود علاقة عكسية منطقية اقتصادياً واحصائياً عند مستوى معنوية ا +.. بين كل من المساحة المزروعة بمحصول الطماطم الشتوى بالألف فدان (كمتغير تابع) وكل من صافى العائد الفدانى لمحصول الباذنجان بالجنيه فى العام السابق (X6(t-1)) وصافى العائد الفدانى لمحصول البسلة الخضراء بالجنيه فى العام السابق (X9(t-1))، حيث بلغت مرونة استجابة العرض لهما حوالى • ( ..، 10 . . على الترتيب وهذا يعنى أن أى زيادة دقدارها ( \% فى صافى العائد الفدانى لمحصولى الباذنجان والبسلة الخضراء فى العام السابق

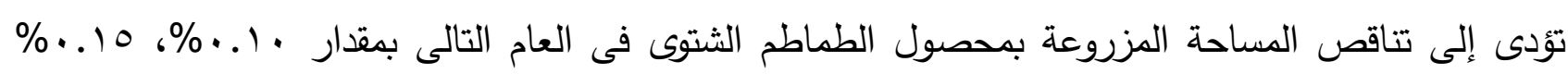
على الترتيب. وقد بلغ معامل التحديد المعدل حوالى ب^.. ، مما يعنى أن ب^\% من التغيرات الحادثة فى المساحة المزروعة بمحصول الطماطم الشتوى ترجع إلى المتغيرات الموجودة بنموذج الاستجابة. وقد ثبت معنوية النموذج ككل عند مستوى معنوية ا ...

ا ـ أحمد حسن أبو شامة عبد الصادق، دراسة اقتصادية لإنتاج واستهلاك محصول الطماطم فى مصر،

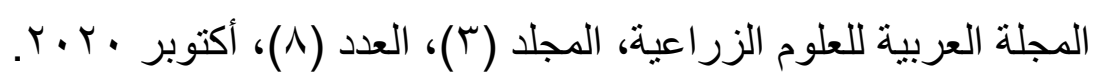
r- جمال الدين زكي، دراسة اقتصادية لاستجابة العرض لبعض المحاصيل الزر اعية فى مصر، رسالة

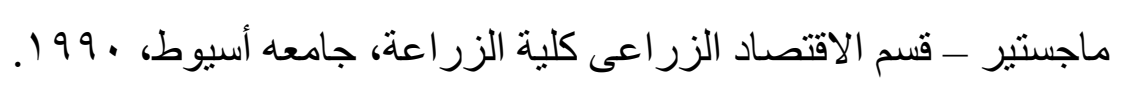

r- حسين حسن على آدم، منتصر محم محمود، دراسة تحليلية لاستجابة عرض محصول الطماطم الثتوى

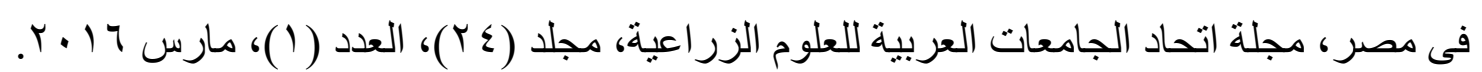
عـ سالي عبد الحميد حسن بو ادي، تقدير إحصائى لدوال استجابة العرض لمحصول البطاطس والطماطم الصيفى بالأراضى الجديدة في جمهورية مصر العربية، مجلة حوليات العلوم الزر اعية بمشتهر، مجلد

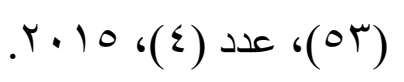


0ـ منى عباس درويش، دراسة اقتصادية لاستجابة عرض محصول البطاطس فى مصر ، المجلة المصرية

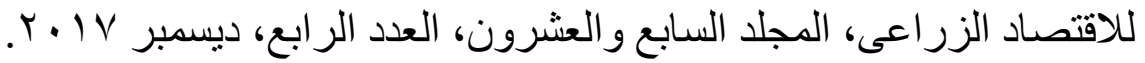
7ـ ـ نادية عبد الله الغريب، در اسة تحليلية لاستجابة عرض محصول الطماطم الصيفى فى الأر اضى الجديدة،

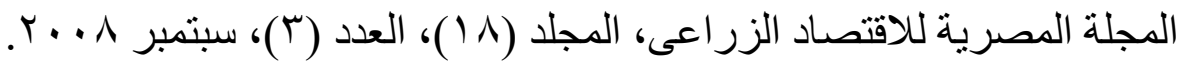
V- وزارة الزر اعة واستصلاح الأراضى، قطاع الشئون الاقتصادية، الإدارة المركزية للاقتصاد الزراعى، نشرة الاقتصاد الزر اعي، أعداد مختلفة.

الملحق جدول رقم ( ) : المتغيرات الداخلة فى تقدير دوال استجابة العرض لمحصول الطماطم الشتوى طبقاً للإنتاجية الفدانية

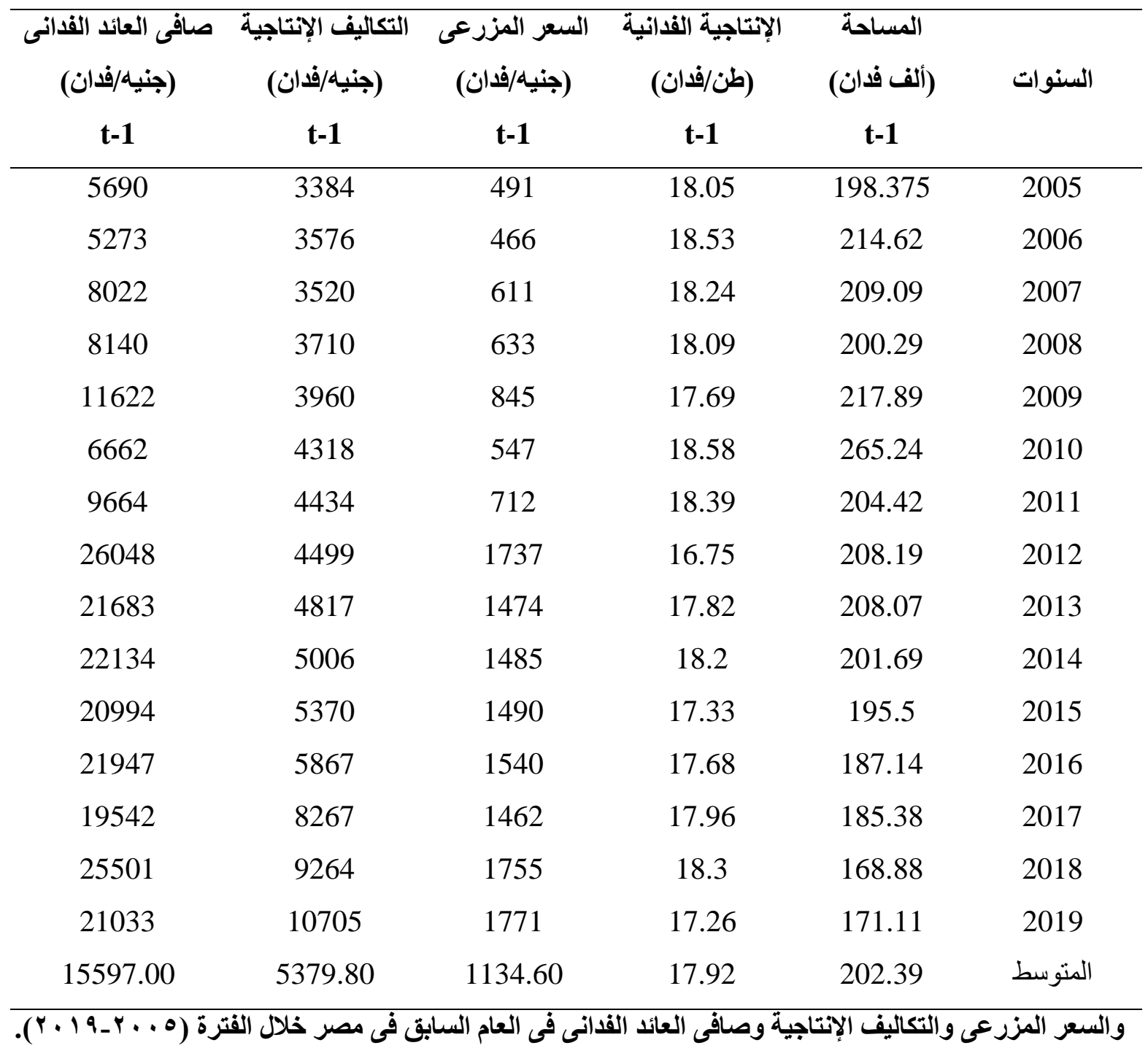

المصدر : جمعت وحسب من: وزارة الزراعة واستصلاح الأر اضى، قطاع الشئون الاقتصادية، الإدارة المركزية للاقتصاد الزر اعى، نشرة الاقتصاد الزر اعى، أعداد مختلفة. 
فايقة عباس قرنى أحمد، وآخرون، تقدير دالة استجابة العرض لمحصول الطماطم الثتوى فى مصر

Abstract

The tomato crop is one of the most important vegetable crops in Egypt, as it receives great attention from the state, the farmer, and the consumer. Supply response functions for the winter tomato crop in Egypt, in order to determine the most important economic factors affecting the cultivated area of this crop during the period (2005-2019). 


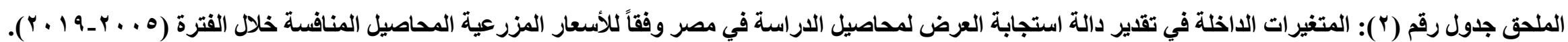

\begin{tabular}{|c|c|c|c|c|c|c|c|c|c|c|}
\hline \multicolumn{10}{|c|}{ السعر المزرعى للمحاصيل المنافسة } & \multirow{3}{*}{ 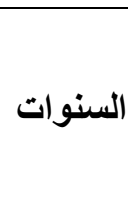 } \\
\hline البسلة (لخضه/طن) & (جنيه/طن) & (جنيه/طن) & (جنيه/طن) & (جنية/طن) & (جنيه/طن) & بنجر السكر & (البرسيم/تشريشه) & البرسيم المستديم) & (جنيه/أردب) & \\
\hline t-1 & t-1 & t-1 & $\mathrm{t}-1$ & $t-1$ & t-1 & t-1 & $\mathrm{t}-1$ & t-1 & $t-1$ & \\
\hline 629 & 521 & 0 & 0 & 491 & 315 & 158 & 1026 & 1026 & 150 & 2005 \\
\hline 687 & 552 & 541 & 0 & 466 & 296 & 160 & 1148 & 1148 & 168 & 2006 \\
\hline 911 & 640 & 714 & 0 & 611 & 480 & 171 & 1209 & 1209 & 169 & 2007 \\
\hline 1210 & 655 & 732 & 0 & 633 & 603 & 187.5 & 1227 & 1227 & 173 & 2008 \\
\hline 1476 & 1058 & 1765 & 0 & 845 & 659 & 231 & 1819 & 1819 & 383 & 2009 \\
\hline 1511 & 1136 & 1785 & 1584 & 547 & 707 & 317.22 & 2074 & 2074 & 242 & 2010 \\
\hline 1561 & 954 & 1850 & 1614 & 712 & 755 & 263 & 2176 & 2176 & 272 & 2011 \\
\hline 2085 & 1325 & 1884 & 1637 & 1737 & 840 & 355 & 3006 & 3006 & 352 & 2012 \\
\hline 2435 & 1444 & 1941 & 1672 & 1474 & 858 & 363.5 & 3570 & 3570 & 378 & 2013 \\
\hline 2689 & 1762 & 2020 & 1690 & 1485 & 876 & 386.7 & 3655 & 3655 & 387 & 2014 \\
\hline 2701 & 1792 & 2019 & 1699 & 1490 & 959 & 370.07 & 3716 & 3716 & 411 & 2015 \\
\hline 2966 & 1852 & 2060 & 1724 & 1540 & 1041 & 378.52 & 3866 & 3866 & 413 & 2016 \\
\hline 2976 & 1831 & 2062 & 1733 & 1462 & 1052 & 379.37 & 3971 & 3971 & 416 & 2017 \\
\hline 3957 & 2374 & 2233 & 2028 & 1755 & 1932 & 534 & 4831 & 4831 & 564 & 2018 \\
\hline 3967 & 2382 & 2221 & 2034 & 1771 & 1998 & 600 & 5288 & 5288 & 564 & 2019 \\
\hline 2117.40 & 1351.87 & 1588.47 & 1161.00 & 1134.60 & 891.40 & 323.66 & 2838.80 & 2838.80 & 336.13 & المتوسط \\
\hline
\end{tabular}




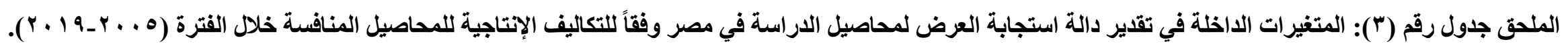

\begin{tabular}{|c|c|c|c|c|c|c|c|c|c|c|}
\hline \multicolumn{10}{|c|}{ التكاليف الإنتاجية للمحاصيل المنافسة } & \multirow{3}{*}{ 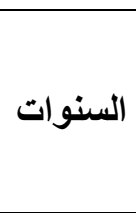 } \\
\hline البسلة الخضر اءو & الكوسية) & (جنيله) & الباذنجان & الطماطم & (البصله) & بنجر السكر & البرسيم تحريش (جيه) & البرسيم المستليم) & (جنيه) & \\
\hline$t-1$ & $\mathrm{t}-1$ & $\mathrm{t}-1$ & t-1 & t-1 & $\mathrm{t}-1$ & t-1 & t-1 & t-1 & $t-1$ & \\
\hline 1956 & 2119 & 0 & 0 & 3384 & 2486 & 1857 & 638 & 1116 & 1904 & 2005 \\
\hline 2129 & 2129 & 2592 & 0 & 3576 & 2632 & 1856 & 650 & 1130 & 1981 & 2006 \\
\hline 2356 & 2243 & 2830 & 0 & 3520 & 2791 & 1886 & 680 & 1193 & 2143 & 2007 \\
\hline 2648 & 2218 & 3226 & 0 & 3710 & 2827 & 1959 & 674 & 1273 & 2444 & 2008 \\
\hline 3198 & 2645 & 4040 & 0 & 3960 & 3040 & 2368 & 952 & 1675 & 3145 & 2009 \\
\hline 3617 & 3327 & 4250 & 3145 & 4318 & 3290 & 2697 & 1194 & 1933 & 3459 & 2010 \\
\hline 3808 & 4312 & 4450 & 3350 & 4434 & 3438 & 3003 & 1256 & 2096 & 3680 & 2011 \\
\hline 3967 & 4520 & 4685 & 3783 & 4499 & 3637 & 3457 & 1294 & 2357 & 4069 & 2012 \\
\hline 4272 & 4957 & 4934 & 4510 & 4817 & 3612 & 4092 & 1499 & 2620 & 4425 & 2013 \\
\hline 4403 & 5333 & 4953 & 4580 & 5006 & 3767 & 4393 & 1644 & 3161 & 4808 & 2014 \\
\hline 4547 & 5490 & 5137 & 4899 & 5370 & 4090 & 4869 & 2245 & 3394 & 5271 & 2015 \\
\hline 4659 & 6066 & 5225 & 5113 & 5867 & 4397 & 5316 & 2338 & 3540 & 5627 & 2016 \\
\hline 6772 & 8090 & 7385 & 7313 & 8267 & 6762 & 6853 & 4190 & 4956 & 7054 & 2017 \\
\hline 8276 & 10369 & 8897 & 9696 & 9264 & 9357 & 7394 & 4621 & 6086 & 8991 & 2018 \\
\hline 8679 & 11267 & 9417 & 10322 & 10705 & 10949 & 8613 & 4863 & 6584 & 10631 & 2019 \\
\hline 4352.47 & 5005.67 & 4801.40 & 3780.73 & 5379.80 & 4471.67 & 4040.87 & 1915.87 & 2874.27 & 4642.13 & المتوسط \\
\hline
\end{tabular}




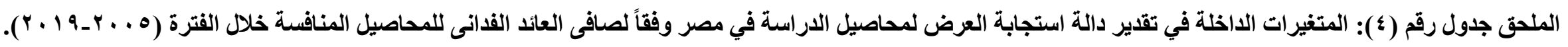

\begin{tabular}{|c|c|c|c|c|c|c|c|c|c|c|}
\hline \multicolumn{10}{|c|}{ صافى العائد القدانى للمحاصيل المنافسة } & \multirow[b]{2}{*}{ 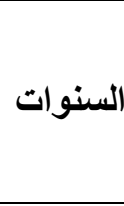 } \\
\hline البسلة الخضر اء & $\begin{array}{c}\text { (الكوسية) } \\
\text { t-1 } \\
\text { t-1 }\end{array}$ & $\begin{array}{c}\text { (القلفل } \\
\text { t-1 } \\
\text { t-1 }\end{array}$ & (جنيه) & $\begin{array}{c}\text { الطماطم) } \\
\text { t-1 }\end{array}$ & $\begin{array}{c}\text { البصله } \\
\text { t-1 } \\
\text { t-1 }\end{array}$ & $\begin{array}{c}\text { بنجر السكر) } \\
\text { t-1 } \\
\text { t-1 }\end{array}$ & $\begin{array}{c}\text { البرسيم تحريشه (جنيه) } \\
\text { t-1 }\end{array}$ & $\begin{array}{c}\text { البرسيم المستديم } \\
\text { t-1 } \\
\text { t-1 }\end{array}$ & $\begin{array}{c}\text { (القمت } \\
\text { t-1 } \\
\text { t-1 }\end{array}$ & \\
\hline 1120 & 1747 & 0 & 0 & 5690 & 1655 & 1365 & 1414 & 2988 & 1666 & 2005 \\
\hline 1182 & 1818 & 773 & 0 & 5273 & 1204 & 1755 & 1646 & 3462 & 1956 & 2006 \\
\hline 2090 & 2474 & 1911 & 0 & 8022 & 3380 & 1722 & 1738 & 3643 & 1863 & 2007 \\
\hline 3160 & 2020 & 1656 & 0 & 8140 & 5287 & 2489 & 1780 & 3635 & 1769 & 2008 \\
\hline 3474 & 3893 & 7132 & 0 & 11622 & 6100 & 2578 & 2686 & 5601 & 5159 & 2009 \\
\hline 3376 & 5078 & 7827 & 16541 & 6662 & 6390 & 4230 & 2954 & 6363 & 2190 & 2010 \\
\hline 3071 & 3634 & 9290 & 16323 & 9664 & 7069 & 3051 & 3096 & 6608 & 1977 & 2011 \\
\hline 5205 & 5102 & 9093 & 14689 & 26048 & 8394 & 3964 & 4718 & 9667 & 3884 & 2012 \\
\hline 4794 & 6296 & 7696 & 14484 & 21683 & 8740 & 4628 & 5641 & 11660 & 4358 & 2013 \\
\hline 7273 & 8088 & 9330 & 15659 & 22134 & 9441 & 4959 & 5666 & 11459 & 4274 & 2014 \\
\hline 7256 & 9496 & 10040 & 14597 & 20994 & 10422 & 4170 & 5187 & 11470 & 4047 & 2015 \\
\hline 7938 & 9057 & 6597 & 13470 & 21947 & 10815 & 3838 & 5394 & 11924 & 3941 & 2016 \\
\hline 6956 & 6563 & 5843 & 15029 & 19542 & 8375 & 1810 & 3752 & 10928 & 2573 & 2017 \\
\hline 9048 & 10271 & 7487 & 19897 & 25501 & 20421 & 4797 & 5041 & 13238 & 3824 & 2018 \\
\hline 9577 & 7610 & 14401 & 17615 & 21033 & 18368 & 5414 & 5713 & 14568 & 2142 & 2019 \\
\hline 5034.67 & 5543.13 & 6605.07 & 10553.60 & 15597.00 & 8404.07 & 3384.67 & 3761.73 & 8480.93 & 3041.53 & المتوسط \\
\hline
\end{tabular}

